JURNAL INOVASI DAN KREATIVITAS (JIKa)

Volume 1 Nomor 2 September 2021;

p-ISSN 2776-1843, e-ISSN 2807-8047

DOI: $10.30656 / j i k a . v 1 i 2.4246$

https://e-jurnal.lppmunsera.org/index.php/JIKa

SK No. 0005.27761843/K.4/SK.ISSN/2021

\title{
Implementasi Aplikasi PANGKAS (Gampang Ngurus Berkas) pada Pelayanan Publik di Dinas Komunikasi dan Informatika Kota Tangerang
}

\section{Implementation of the PANGKAS (Gampang Ngurus Berkas) Application on Public Services at Dinas Komunikasi dan Informatika Kota Tangerang}

\author{
R. S Budi Satriyo ${ }^{a}$, Bambang Kurniawan ${ }^{a}$ R. Asti Aulia ${ }^{a}$ \\ a Program Studi Ilmu Pemerintahan STISIP YUPPENTEK rbudisatriyo007@gmail.com \\ a Program Studi Ilmu Pemerintahan STISIP YUPPENTEK bengsq.0701@gmail.com \\ a Program Studi Ilmu Pemerintahan STISIP YUPPENTEK Astiaulia@gmail.com
}

\begin{abstract}
Problem: there are obstacles in the operation of this Pangkas, there are five sub-districts out of a total of 104 sub-districts that are still low in the use of the pangkas application for services to the community.

Objective: This study aims to determine the implementation of the Pangkas application used by $R T / R W$ in serving community administration and what are the supporting factors and inhibiting factors in its implementation.

Methodology: The research method is a case study with a qualitative approach. The data collection procedure in this study used participatory observation and interviews (to 10 informants, the Head of the Ministry of Communication and Informatics, Camat, Lurah and RT/RW in Tangerang City) and documentation. The technique used is a purposive sampling technique, the data analysis in this study uses the Miles and Huberman model.

Research Findings/Results: The results of this study are that the Pangkas Application is one of the efforts of the Tangerang City Government in realizing excellent service for its citizens, in carrying out this program the Kominfo Service is supported by the District, the Village continues to carry out socialization and training to $R T$ and $R W$ regarding the use of the Pangkas application, although there are still obstacles in some kelurahan in the full implementation of the Pangkas application, the community's ability to use IT is still lacking, infrastructure, human resources, education and capabilities and abilities of $R T$ and $R W$ are not all in accordance with the provisions. Recommendations and suggestions for the government, must really ensure that this application program can be run at the $R T / R W$ level by coordinating the sub-districts with regard to socialization, training, capacity building and capacity of $R T / R W$ and the fulfillment of $R T / R W$ infrastructure facilities is the responsibility of the government for the sake of The achievement of services to the community, in this case is the responsibility of the District and Kelurahan in its fulfillment.
\end{abstract}

Research type: Field research

Keywords: Implementation, PANGKAS Application (Easy File Management) and public services 


\section{Abstrak}

Masalah: terdapat kendala dalam pengoperasikan Pangkas ini, terdapat lima kelurahan dari total 104 kelurahan yang masih rendah dalam pengunaan aplikasi pangkas untuk pelayananan kepada masysrakat.

Tujuan: Penelitian ini bertujuan untuk mengetahui implementasi aplikasi Pangkas yang digunakan oleh RT/RW dalam melayani administrasi masyarakat serta apa saja yang menjadi faktor pendukung dan faktor penghambat dalam pelaksanaannya.

Metodologi: Metode dalam penelitian adalah studi kasus dengan pendekatan kualitatif. Prosedur pengumpulan data dalam penelitian ini menggunakan observasi partisipatif dan juga wawancara (pada 10 oran informan, Kepala Dinas Kominfo, Camat, Lurah dan RT/RW di Kota Tangerang) serta dokumentasi. Teknik yang digunakan merupakan teknik purposive sampling, analisis data dalam penelitian ini menggunakan model Miles dan Huberman.

Temuan/Hasil Penelitian: Hasil penelitian ini bahwa Aplikasi Pangkas ini adalah salah satu upaya Pemkot Tangerang dalam mewujudkan pelayanan prima bagi warganya, dalam menjalankan program ini Dinas Kominfo didukung oleh Kecamatan, Kelurahan terus melakukan sosialisasi dan pelatihan kepada RT dan RW tentang pengunaan aplikasi Pangkas, walaupun masih terdapat kendala di beberapa kelurahan dalam implementasi sepenuhnya aplikasi Pangkas dari kemampuan masyarakat dalam mengunakan IT yang masih kurang, sarana prasarana, sumber daya manusia, pendidikan dan kemampuan serta kemampuan RT dan RW yang belum semuanya sesuai dengan ketentuan. Rekomendasi dan saran bagi pemerintah, harus benar benar memastikan bahwa program aplikasi ini dapat di jalankan di tingkat RT/RW dengan mengkoordinasikan kecamatan berkaitan dengan sosialisasi, pelatihan, peningkatan kemampuan dan kapasitas RT/RW dan pemenuhan sarana prasarana RT/RW menjadi tanggung jawab pemerintah demi tercapainya pelayanan terhadap masyarakat, dalam hal ini menjadi tanggungjawab Kecamatan dan Kelurahan dalam pemenuhanya.

Jenis penelitian: Riset lapangan

Kata kunci: Implementasi, Aplikasi PANGKAS (Gampang Ngurus Berkas) dan pelayanan publik

\section{A. PENDAHULUAN}

Pelayanan publik adalah kegiatan atau rangkaian kegiatan dalam rangka pemenuhan kebutuhan pelayanan sesuai dengan peraturan perundang-undangan bagi setiap warga negara dan penduduk atas barang, jasa, dan atau pelayanan administratif tertentu (Adawiyah. 2018), sedangkan menurut UU No. 25/2009, yang dimaksud dengan pelayanan publik adalah kegiatan atau rangkaian kegiatan dalam rangka pemenuhan kebutuhan pelayanan sesuai dengan peraturan perundang-undangan bagi setiap warga negara dan penduduk atas barang, jasa, dan/ atau pelayanan administratif yang disediakan oleh penyelenggara pelayanan publik. Firdausijah dan Ami Priatna. 2020, untuk dapat memberikan pelayanan yang memuaskan bagi pengguna jasa, penyelenggara pelayanan harus memenuhi asas-asas pelayanan sebagai berikut (Keputusan MENPAN Nomor 63 Tahun 2004) transparansi, akuntabilitas, kondisional, partisipatif, kesamaan hak. Pelayanan publik khususnya bagi masyarakat menjadi kebutuhan di era teknologi saat ini, Kota Tangerang melalui Dinas Komunikasi dan Informatika mengembangkan urusan administrasi masyarakat yang dimulai dari tingkat RT dan RW dengan membuat inovasi yaitu aplikasi berbasis android untuk memudahkan RT dan RW dalam melayani masyarakat yaitu dengan membangun aplikasi Pangkas (Gampang Ngurus Berkas). Aplikasi Pangkas adalah aplikasi yang khusus digunakan untuk pemangku wilayah RT dan RW dalam melayani warga di wilayahnya seperti pengurusan administrasi surat untuk keperluan 
surat keterangan, dan lain-lain yang diproses secara online.

Akan tetapi, masih terdapat kendala dalam pengoperasikan Pangkas ini, masih terdapat wilayah yang belum seluruhnya para ketua RT dan RW dapat mengoperasikan aplikasi ini dengan baik sehingga dirasa aplikasi ini belum berjalan secara optimal seperti yang diharapkan. Penelitian ini bertujuan untuk mengetahui implementasi aplikasi Pangkas yang digunakan oleh RT/RW dalam melayani administrasi masyarakat serta apa saja yang menjadi faktor pendukung dan faktor penghambat dalam pelaksanaannya. Berikut ini data total rekap aplikasi pangkas per wilayah kecamatan di Kota Tangerang periode sampai dengan bulan Agustus tahun 2021:

Tabel 1.1

Rekapan Penggunaan Aplikasi Pangkas Periode Bulan Agustus Tahun 2021

\begin{tabular}{|l|l|l|}
\hline No & \multicolumn{1}{|c|}{ Kecamatan } & \multicolumn{1}{|c|}{$\begin{array}{c}\text { Total Rekap } \\
\text { Pangkas }\end{array}$} \\
\hline 1 & Kecamatan Cibodas & 16.994 \\
\hline 2 & Kecamatan Jatiuwung & 9.365 \\
\hline 3 & Kecamatan Karawaci & 1.124 \\
\hline 4 & Kecamatan Pinang & 663 \\
\hline 5 & Kecamatan Ciledug & 483 \\
\hline 6 & Kecamatan Neglasari & 490 \\
\hline 7 & Kecamatan Cipondoh & 324 \\
\hline 8 & Kecamatan Periuk & 373 \\
\hline 9 & Kecamatan Larangan & 348 \\
\hline 10 & $\begin{array}{l}\text { Kecamatan } \\
\text { Tangerang }\end{array}$ & 168 \\
\hline 11 & $\begin{array}{l}\text { Kecamatan Batu } \\
\text { Ceper }\end{array}$ & 581 \\
\hline 12 & $\begin{array}{l}\text { Kecamatan Karang } \\
\text { Tengah }\end{array}$ & 45 \\
\hline 13 & Kecamatan Benda & 24 \\
\hline \multicolumn{2}{|c|}{ Total } & $\mathbf{3 0 . 9 8 2}$ \\
\hline
\end{tabular}

Sumber : Rekap Pelayanan Administrasi Terpadu Kecamatan di Kelola oleh Dinas Kominfo Kota Tangerang per Bulan Agustus 2021

Berdasarkan tabel 1.1 maka dapat dijelaskan bahwa wilayah Kecamatan Cibodas dengan pengguna aplikasi Pangkas terbanyak periode sampai dengan bulan Agustus tahun 2021 yaitu sebanyak 16.994 pengguna dan wilayah Kecamatan Benda dengan pengguna aplikasi Pangkas terendah sampai dengan periode bulan Agustus 2021 yaitu sebanyak 24 pengguna. Maka jumlah pengguna aplikasi pangkas sampai dengan bulan Agustus 2021 total penggunanya mencapai 30.982 .

Berikut ini adalah rekapan data jumlah pengguna aplikasi pangkas terendah di kelurahan wilayah Kota Tangerang adalah sebagai berikut :

Tabel 1.2

Daftar Kelurahan Terendah Pengguna Aplikasi Pangkas

Sampai Periode Bulan Agustus 2021

\begin{tabular}{|l|c|c|}
\hline No & Kelurahan & $\begin{array}{c}\text { Total Rekap } \\
\text { Pangkas }\end{array}$ \\
\hline 1 & $\begin{array}{c}\text { Kelurahan } \\
\text { Selapajang Jaya }\end{array}$ & 0 \\
\hline 2 & $\begin{array}{c}\text { Kelurahan } \\
\text { Kedaung Wetan }\end{array}$ & 0 \\
\hline 3 & $\begin{array}{c}\text { Kelurahan } \\
\text { Sudimara Selatan }\end{array}$ & 1 \\
\hline 4 & $\begin{array}{c}\text { Kelurahan Poris } \\
\text { Gaga Baru }\end{array}$ & 1 \\
\hline 5 & $\begin{array}{c}\text { Kelurahan Parung } \\
\text { Serab }\end{array}$ & 3 \\
\hline & Total & Retrap Pelayanan \\
\hline
\end{tabular}

Sumber : Rekap Pelayanan Administrasi Terpadu Kecamatan di Kelola oleh Dinas Kominfo Kota Tangerang per Bulan Agustus 2021

Berdasarkan tabel 1.2 data diatas masih terdapat lima kelurahan terendah dalam penggunaan aplikasi ini, sehingga apabila permasalahan ini akan menghambat implementasi pelayanan publik berbasis online. Manurung, dkk. 2018, yang meneliti Implementasi Kebijakan Pelayanan Administrasi Terpadu Kecamatan (Paten) Terhadap Kualitas Pelayanan Publik di Kecamatan Sidikalang Kabupaten Dairi menyatakan bahwa administrasi terpadu sangat membantu dalam proses pelayanan dan meningkatkan kepuasan pelayanan publik di masyarakat. Sukardi, dkk. 2021, Implementasi Difusi Inovasi Aplikasi Super RT Sebagai Fasilitas Pelayanan Publik di Kelurahan Lok Tuan Kota Bontang, Hasil analisis adalah ketua RT langsung 
mengimplementasikan inovasi aplikasi super RT dalam melayani warganya.

\section{B. KERANGKA TEORI}

Rahyunir. 2018. Pada hakekatnya pemerintahan ada dan diadakan untuk melayani kepentingan dan pemenuhan kebutuhan masyarakat khususnya kebutuhan dasar manusia yakni rasa aman dan tertib dan tentram, sehingga fungsi dasar pemerintah adalah pelayanan, baik menyelenggarakan pelayanan pemerintahan, pelayanan pembangunan dan pelayanan kemasyarakatan.

Tiong. 2018. Pelayanan adalah uatu kegiatan atau serangkaian kegiatan yang kurang lebih tidak berwujud seperti biasanya, tetapi tidak harus berlangsung dalam interaksi antara pelanggan dan layanan karyawan dan atau sumber daya fisik atau sistem yang baik dan atau penyedia layanan, yang disediakan sebagai solusi untuk memecahkan masalah pelanggan. Zuraeva dan Novianita Rulandari. 2020. Pelayanan adalah cara melayani (membantu mengurus atau menyiapkan segala kebutuhan yang diperlukan seseorang). Sementara itu, fiskus merupakan petugas pajak. Jadi, pelayanan fiskus dapat diartikan sebagai cara petugas pajak dalam membantu, mengurus, atau menyiapkan segala keperluan yang dibutuhkan seseorang.

\section{Indikator Pelayanan}

Zuraeva dan Novianita Rulandari. 2020. Terdapat 10 kategori Kualitas Pelayanan. Ke- 10 kategori ini mereka sebut "Service Quality Determinants." Berikut adalah ringkasan ke-10 determinan tersebut: Reliability, Responsiveness, Competence, Access, Courtesy, Communication, Credibility, Security, Understanding/Knowing The Customer, Tangibles.

Suryantoro dan Yan Kusdyana. 2020. Pelayanan publik pun
Berdasarkan Keputusan Menteri Pendayagunaan Aparatur Negara Nomor 63 Tahun 2003, definisi dari pelayanan umum adalah : Segala bentuk pelayanan yang dilaksanakan oleh instansi pemerintah di pusat, di daerah, dan di lingkungan Badan Usaha Milik Negara atau Badan Usaha Milik Daerah dalam bentuk barang dan atau jasa, baik dalam rangka pelaksanaan ketentuan peraturan perundang-undangan. Sedangkan menurut Bab 1 Pasal 1 Ayat 1 UU No. 25/2009, yang dimaksud dengan pelayanan publik adalah kegiatan atau rangkaian kegiatan dalam rangka pemenuhan kebutuhan pelayanan sesuai dengan peraturan perundang-undangan bagi setiap warga negara dan penduduk atas barang, jasa, dan/ atau pelayanan administratif yang disediakan oleh penyelenggara pelayanan publik.

\section{Asas Pelayanan Publik}

Firdausijah dan Ami Priatna. 2020. Untuk dapat memberikan pelayanan yang memuaskan bagi pengguna jasa, penyelenggara pelayanan harus memenuhi asas-asas pelayanan sebagai berikut (Keputusan MENPAN Nomor 63 Tahun 2004) : Transparans, Akuntabilitas, Kondisional , Partisipatif, Kesamaan Hak

\section{Faktor - Faktor Pelayanan Publik}

Wuri. 2019. Kualitas pelayanan terbagi menjadi dua bagian yaitu kualitas pelayanan internal dan eksternal. Masing-masing bagian tersebut dipengaruhi oleh beberapa faktor yang cukup penting, yaitu sebagai berikut :

a. Faktor yang mempengaruhi kualitas pelayanan internal (interaksi pegawai organisasi), yaitu pola manajemen umum organisasi, penyediaan fasilitas pendukung, pengembangan sumber daya manusia, iklim kerja dan keselarasan hubungan kerja, serta pola insentif. 
b. Faktor yang mempengaruhi kualitas pelayanan eksternal (pelanggan eksternal), yaitu pola layanan dan tata cara penyediaan layanan, pola layanan distribusi jasa, pola layanan penjualan jasa, dan pola layanan dalam penyampaian jasa.

\section{Bentuk-Bentuk Pelayanan Publik}

Ramadhani. 2017. Terdapat tiga macam bentuk pelayanan diantaranya adalah :

1. Pelayanan Dengan Lisan

Pelayanan dengan lisan ini dilakukan oleh petugas-petugas bidang hubungan masyarakat (humas), bidang layanan informasi dan bidnag lain yang tuganya memberikan penjelasan atau keterangan kepada masyarakat mengenai berbagai fasilitas layanan yang tersedia.

Agar pelayanan lisan berhasil sesuai dengan apa yang diharapkan, adanya syarat- syarat yang harus dipenuhi oleh pelaku pelayanan, yaitu :

a. Memahami benar masalahmasalah yang termasuk kedalam bidang tugasnya

b. Mampu memberikan penjelasan apa-apa saja yang perlu dengan lancar, singkat tetapi cukup jelas sehingga memuaskan bagi mereka yang ingin memperoleh kejelasan mengenai sesuatu.

c. Bertingkah laku sopan dan ramah tamah

d. Harus dalam keadaan sepi, tidak berbincang, dan berbicara dengan sesama pegawai, karena menimbulkan kesan tidak disiplin dan melalaikan tugas.

2. Pelayanan Dengan Tulisan

Dalam bentuk tulisan, pelayanan yang diberikan dapat berupa pemberian penjelasan kepada masyarakat dengan penerangannya berupa tulisan suatu informasi mengenai hal atau masalah yang sedang terjadi. Pelayanan dalam bentuk tulisan terdiri dari dua macam yaitu :

a. Layanan yang berupa petunjuk, informasi ya ng sejenis yang dilakukan kepada orang-orang yang berkepentingan agar memudahkan mereka dalam berurusan dengan instansi atau lembaga.

b. Pelayanan yang berupa reaksi tertulis atau permohonan, laporan, keluhan, pemberitahuan dan sebagainya.

3. Pelayanan Bentuk Perbuatan

Layanan dalam bentuk perbuatan adalah pelayanan yang diberikan dalam bentuk perbuatan atau hasil perbuatan, bukan sekedar kesanggupan atau penjelasan secara lisan.

\section{Peran Pemerintah dalam Pelayanan Publik}

Ramadhani. 2017. peran pemer intah atau dengan kata lainnya birokrasi memiliki peranan kedudukan, dan fungsi yang sangat signifikan dalam penyelenggaraan pemerintahan, yang tidak dapat digantikan fungsinya oleh lembaga-lembaga lainnya. Birokrasi ini tidak hanya menyangkut kepada birokrasi tetapi akan sangat terkait dengan organisasi dan manajemen pengelolaan pemerintahan, pembangunan dan publik.

\section{Masyarakat}

Aini, dkk. 2018. Masyarakat menurut Abdul Tsani adalah berkumpul, bersama, hidup bersama dengan saling berhubungan dan saling mempengaruhi. Dalam bermasyarakat tidak akan pernah luput yang namanya interaksi sosial. Dalam proses interaksi tersebut akan sangat diperlukan adanya komunikasi sosial, dan di dalam komunikasi sosial setiap individu tentu mempunyai pikiran, visi dan misi yang berbeda. Widayati dan Faizal Aco. 2019. Masyarakat adalah sekelompok manusia 
yang telah cukup lama hidup dan bekerja sama sehingga dapat terbentuk organisasi yang mengatur setiap individu dalam masyarakat tersebut dan membuat setiap individu dalam masyarakat dapat mengatur diri sendiri dan berpikir tentang dirinya sebagai satu kesatuan sosial dengan batasan tertentu.

\section{Implementasi}

Menurut Imbar, dkk. 2020, Implementasi adalah pelaksanaan atau penerapan.

mengimplementasikan sedangkan adalah melaksanakan atau menerapkan. implementasi adalah tindakan-tindakan yang harus dilakukan oleh sekelompok individu yang telah terhadap program tersebut. Maka penjelasan secara detail impelementasi adalah tindakantindakan yang dilakukan oleh individuindividu, pejabat-pejabat, atau kelompok-kelompok pemerintah atau swasta yang diarahkan pada tercapainya tujuan-tujuan yang telah digariskan dalam keputusan kebijakan.

Hidayat dan Irma Fitriani, 2020. Implemenstasi adalah rangkuman dari berbagai kegiatan yang didalamnya sumber daya manusia menggunakan sumber daya lain untuk mancapai sasaran dan strategi.

\section{Aplikasi}

Pengertian aplikasi menurut Bahagia dan Sriwinar, 2021. Istilah aplikasi berasal dari bahasa inggris application yang berarti penerapan, lamaran ataupun penggunaan. Sedangkan secara istilah, pengertian aplikasi adalah suatu program yang siap untuk digunakan yang dibuat untuk melaksanakan suatu fungsi bagi pengguna jasa aplikasi serta penggunaan aplikasi lain yang dapat digunakan oleh suatu sasaran yang akan dituju. Menurut kamus komputer eksekutif, aplikasi mempunyai arti yaitu pemecahan masalah yang menggunakan salah satu teknik pemrosesan data aplikasi yang biasanya berpacu pada sebuah komputasi yang diinginkan atau diharapkan maupun pemrosesan data yang diharapkan. Sudirman, 2020. Mengungkapkan bahwa aplikasi adalah suatu subkelas perangkat lunak komputer yang memanfaatkan kemampuan komputer langsung untuk melakukan suatu tugas yang diinginkan pengguna. Biasanya dibandingkan dengan perangkat lunak sistem yang mengintegrasikan berbagai kemampuan komputer, tapi tidak secara langsung menerapkan kemampuan tersebut untuk mengerjakan suatu tugas yang menguntungkan pengguna.

\section{Aplikasi Berbasis Mobile PANGKAS}

Pramana, 2019. aplikasi mobile berasal dari kata application dan mobile. Application yang artinya penerapan, lamaran, penggunaan. Secara istilah aplikasi adalah program siap pakai yang direka untuk melaksanakan suatu fungsi bagi pengguna atau aplikasi yang lain dan dapat digunakan oleh sasaran yang dituju sedangkan mobile dapat di artikan sebagai perpindahan dari suatu tempat ke tempat yang lain.

Aplikasi tersebut dinamakan Gampang Ngurus Berkas atau disingkat Pangkas. Aplikasi tersebut melayani beragam berkas administrasi seperti surat pengantar kelakuan baik, surat izin keramaian, surat keterangan kematian, surat keterangan belum menikah, setelah divalidasi Ketua RT RW dalam surat keterangan yang diajukan via aplikasi Pangkas bisa digunakan dan merupakan tanda validasi yang sah. Aplikasi Gampang Ngurus Berkas (Pangkas) sudah disosialisasikan kurang lebih di 5.000 RT RW (Rukun Tetangga dan Rukun Warga) untuk mempermudah pengurusan berkas ke masyarakat. 


\section{METODE PENELITIAN}

Metode penelitian yang penulis gunakan adalah metode penelitian kualitatif. Penelitian kualitatif adalah penelitian tentang riset yang bersifat deskriptif dan cenderung menggunakan analisis. Proses dan makna (perspektif subyek) lebih ditonjolkan dalam penelitian kualitatif. Landasan teori dimanfaatkan sebagai pemandu agar fokus penelitian sesuai dengan fakta di lapangan. Selain itu landasan teori juga bermanfaat untuk memberikan gambaran umum tentang latar penelitian dan sebagai bahan pembahasan hasil penelitian. Terdapat perbedaan mendasar antara peran landasan teori dalam penelitian kuantitatif dengan penelitian kualitatif. Dalam penelitian kuantitatif, penelitian berangkat dari teori menuju data, dan berakhir pada penerimaan atau penolakan terhadap teori yang digunakan; sedangkan dalam penelitian kualitatif peneliti bertolak dari data, memanfaatkan teori yang ada sebagai bahan penjelas, dan berakhir dengan suatu "teori" (https://id.wikipedia.org/wiki/Peneliti an kualitatif).

Menurut Strauss dan Corbin, yang dimaksud dengan penelitian kualitatif adalah jenis penelitian yang menghasilkan penemuan-penemuan yang tidak dapat dicapai (diperoleh) dengan menggunakan prosedurprosedur statistik atau cara-cara lain dari kuantifikasi (pengukuran). Penelitian kualitatif secara umum dapat digunakan untuk penelitian tentang kehidupan masyarakat, sejarah, tingkah laku, fungsionalisasi organisasi, aktivitas sosial. Salah satu alasan menggunakan pendekatan kualitatif adalah pengalaman para peneliti dimana metode ini dapat digunakan untuk menemukan dan memahami apa yang tersembunyi dibalik fenomena yang kadangkala merupakan sesuatu yang sulit untuk dipahami secara memuaskan.
Bogdan dan Taylor menjelaskan bahwa penelitian kualitatif adalah salah satu prosedur penelitian yang menghasilkan data deskriptif kualitatif berupa katakata tertulis atau lisan dari orang-orang dan prilaku yang diamati.

Istilah penelitian kualitatif menurut Kirk dan Miller pada mulanya bersumber pada pengamatan kualitatif yang dipertentangkan dengan pengamatan kuantitatif. Penelitian kualitatif ini bersifat deskriptif Artinya, data yang dianalisis dari gejala-gejala yang diamati, yang tidak harus selalu berbentuk angka atau koefisien antar variabel. Dan terkadang pada penelitian kualitaatif, memungkinkan adanya data kuantitatif. Akan tetapi, pada penelitian kualitatif, pengumpulan dan pengolahan data umumnya bersifat pengamatan awal hingga akhir. Maka, penyajian analisis data pun akan sedikit berbeda dengan penelitian jenis kuantitatif. Karna itulah penelitian kualitatif lebih condong berada dibawah paradigma fungsionalisme, objektivisme, dan fakta sosial. Berdasarkan penelitian yang penulis lakukan data yang, diperoleh tidak bisa dikuantitatifkan.

Sampel yang diambil dalam penelitian ini purposive sampling, yakni informan yang dianggap memiliki kompetensi dan dapat memberikan informasi yang valid terkait dengan penelitian ini. Dengan mengacu pada pendapat diatas maka infoman kunci (key informan) dalam penelitian ini ditentukan secara sengaja (purposive sampling), yakni informan yang dianggap memiliki kompetensi dan dapat memberikan informasi yang valid terkait dengan penelitian ini (Sebagai Data PrimerJumlah informan ditetapkan sebanyak 10 orang informan, dengan rincian sebagai berikut: 
Tabel 1.3

\section{Informan Penelitian}

\begin{tabular}{|c|c|c|}
\hline No & Informan & $\begin{array}{l}\text { Jenis Informasi Yang } \\
\text { Diperlukan }\end{array}$ \\
\hline 1. & $\begin{array}{l}\text { Kepala Dinas } \\
\text { Kominfo Kota } \\
\text { Tangerang }\end{array}$ & $\begin{array}{l}\text { Informasi mengenai Aplikasi } \\
\text { Pangkas, maksud dan tujuan } \\
\text { serta target Kota Tangerang } \\
\text { dalam mendigitalisasi system } \\
\text { pelayanan public. }\end{array}$ \\
\hline 2. & $\begin{array}{l}\text { Camat } \\
\text { Kecamatan } \\
\text { Jatiuwung Kota } \\
\text { Tangerang }\end{array}$ & $\begin{array}{l}\text { Informasi mengenai fungsi } \\
\text { aplikasi pangkas ini apakah } \\
\text { sudah berjalan sesuai dengan } \\
\text { apa yang diharapkan dan } \\
\text { kesiapan SDM di tingkat } \\
\text { Kecamatan, Kelurahan dalam } \\
\text { mensosialisasikan ke para RT } \\
\text { dan RW }\end{array}$ \\
\hline 3. & $\begin{array}{l}\text { Lurah } \\
\text { kelurahan } \\
\text { Gandasari } \\
\text { Kecamatan } \\
\text { Jatiuwung Kota } \\
\text { Tangerang }\end{array}$ & $\begin{array}{l}\text { Sejauhmana implementasi } \\
\text { Aplikasi Pangkas dan kesiapan } \\
\text { SDM untuk melakukan } \\
\text { sosialisasi ke RT dan RW }\end{array}$ \\
\hline 4 & $\begin{array}{l}\text { Kasi Tapem } \\
\text { dan Kasi } \\
\text { Kemas } \\
\text { Kelurahan } \\
\text { Benda } \\
\text { Kecamatan } \\
\text { Benda }\end{array}$ & $\begin{array}{l}\text { Sejauhmana implementasi } \\
\text { Aplikasi Pangkas, tingkat } \\
\text { sosialisasi, factor pendukung } \\
\text { dan penghambat penggunaan } \\
\text { aplikasi PANGKAS di tingkat } \\
\text { RT dan RW }\end{array}$ \\
\hline 5 & $\begin{array}{l}\text { Dua RW di } \\
\text { Kelurahan } \\
\text { Cibodasari dan } \\
\text { Tiga RT di } \\
\text { Kelurahan } \\
\text { Benda } \\
\text { Kecamatan } \\
\text { Benda }\end{array}$ & $\begin{array}{l}\text { Sejauhmana implementasi } \\
\text { Aplikasi Pangkas, tingkat } \\
\text { sosialisasi ke masysrakat, } \\
\text { factor pendukung dan } \\
\text { penghambat penggunaan } \\
\text { aplikasi PANGKAS di tingkat } \\
\text { RT dan RW }\end{array}$ \\
\hline
\end{tabular}

Adapun sumber data yang digunakan adalah dari data primer dan sekunder.

1. Data primer

Sumber data primer diperoleh dari wawancara dengan Dinas, camat, lurah, RW dan RT yang dianggap memiliki keterkaitan langsung dengan Aplikasi Pangkas.

2. Data Sekunder

Data sekunder yaitu sumber data pelengkap penelitian. Sumber data sekunder diambil dari berbagai literature seperti buku-buku, dokumen-dokumen, baik dari jurnal, internet dan kepustakaan lain. Data sekunder yang diperoleh adalah data berupa dokumen atau berkas dari pihak atau yang menjadi objek penelitian ini seperti buku profil Dinas Kominfo Kota Tangerang, Kecamatan Jatiuwung, Kecamatan Benda, Kelurahan Benda, Kelurahan Gandasari Kecamatan Jatiuwung, Kelurahan Cibodasari Kecamatan Cibodas, dokumen penggunaan aplikasi pangkas per wilayah (RT, RW dan Kelurahan), serta dokumendokumen lainnya yang berkaitan dengan pembahasan dalam penelitian ini.

Teknik pengumpulan data yang digunakan oleh peneliti dalam penelitian ini menggunakan tiga teknik pengumpulan data dikemukakan oleh Sugiyono (2018:227) ketiga teknik pengumpulan data, dalam menggunakan teknik observasi pada penelitian ini, peneliti melakukan pengamatan terhadap aktivitas penggunaan dan pengoperasional aplikasi pangkas meliputi aspek penggunaan dan pengoperasionalan aplikasi pangkas dalam pengurusan administrasi di masysrakat. Dimana peneliti mengamati secara langsung tentang kondisi objek penelitian atau peristiwa yang sedang terjadi saat itu kemudian peneliti 
mencatat kegiatan saat dilapangan. Selanjutnya adalah Teknik Wawancara Mendalam, wawancara mendalam merupakan proses percakapan dengan maksud untuk mengonstruksi mengenai orang, kejadian, kegiatan, organisasi, motivasi, perasaan, dan sebagainya yang dilakukan dua pihak yaitu pewawancara yang mengajukan pertanyaan dengan orang yang diwawancarai. Dalam wawancara ini terdapat dua macam yang dipakai untuk menguji kredibilitas penelitian ini yaitu triagulasi sumber dan triagulasi teknik.

Selanjutnya Analisis data kualitatif yang merupakan upaya yang dilakukan dengan jalan bekerja dengan data, mengorganisasikan data, serta memilih-milihnya menjadi satuan yang dapat dikelola, mensintesiskan, mencari dan menemukan pola, menemukan apa yang penting dan apa yang dipelajari dan memutuskanapa yang dapat diceritakan kepada orang lain. (Lexy J. Moleong, 2018) Analisis data dalam penelitian ini menggunakan model Miles dan Huberman. Analisis data dalam penelitian kualitatif, dilakukan pada saat pengumpulan data berlangsung dan setelah selesai pengumpulan data pada periode tertentu. Pada saat wawancara, peneliti melakukanan alisis terhadap jawaban informan. Bila jawaban informan setelah dianalisis terasa belum memuaskan maka peneliti akan melanjutkan pertanyaan lagi sampai tahap tertentu diperoleh data yang dianggap kredibel. Setelah peneliti melakukan pengumpulan data peneliti melakukan reduksi data (data reduction), penyajian data (data display), penarikan kesimpulan (conclusing drawing/ verification). (Sugiyono, 2017)

\section{HASIL DAN PEMBAHASAN}

Dengan adanya data yang diperoleh dari hasil wawancara penelitian dimaksud, ada beberapa hal yang menjadi bahasan dalam implementasi penggunaan aplikasi Pangkas di Kota Tangerang, sebagai berikut :

1. Pemerintah Kota (Pemkot) Tangerang terus melakukan inovasi guna mempermudah pelayanan pada masyarakatnya. Yaitu, dengan meningkatkan kualitas pelayanan melalui aplikasi Gampang Ngurus Berkas (PANGKAS). Aplikasi tersebut melayani 15 urusan seperti surat pengantar kelakuan baik, surat izin keramaian, surat keterangan kematian, surat keterangan belum menikah dan lainnya. Camat Jatiuwung Edih, S Aplikasi ini adalah salah satu upaya Pemkot Tangerang dalam

mewujudkan pelayanan prima bagi warganya, Kepala Dinas Kominfo Mulyani menambahkan bahwa ke depannya akan terus melakukan pengembangan aplikasi menyesuaikan dengan kebutuhan dan perkembangan zaman.

2. Sosialisasi kepada masysrakat berkaitan dengan aplikasi pangkas dan fungsinya terus dilakukan, selain itu pelatihan pada pengurus RT dan Rw juga terus ditingkatkan. Tetapi tidak dipungkiri bahwa masih belum semua RT dan Rw mengimplementasikan Aplikasi Pangkas ini dengan baik. Lurah Gandasari, Kepala Seksi Pemerintahan Kelurahan Benda menjelaskan masih terdapat kendala dalam implementasi aplikasi Pangkas ini, terutama dari kemampuan masyarakatnya itu sendiri, sumber daya manusia, pendidikan dan penegtahuan. Oleh karenanya pemerintah dalam hal ini kelurahan selalu melakukan sosialisasi dan pembinaan melalui forum $\mathrm{Rt} / \mathrm{Rw}$, dalam mensosialisasikan dan mengadakan pelatihan kepada RT dan 
RW tentang pengunaan dan pemanfaatan aplikasi pangkas

3. Selain terkendala sumberdaya manusia di beberapa RT dan RW tentang pengetahuan dan kemampuan mengunakan IT, masih banyaknya masyarakat yang gaptek sehingga ini menyulitkan para RT dan RW dalam melakukan sosialisasi penggunaan Pangkas ke masysrakat ( RT dan RW Kelurahan Benda, Gandasari, Cibodasari).

4. Sarana prasarana juga menjadi salah satu factor penentu dalam suksesnya program ini, Rohayat (RT 03 Rw 04 Kelurahan Gandasari dan Suhendi RW 04 Kelurahan Gandasari) menjelaskan masih banyak nya RT dan RW yang secara sarana prasarananya kurang, seperti alat komunikasi yang walaupun sudah adroid tapi Ram nya kecil sehingga menghambat dalam mengoperasikan aplikasi pangkas. Selain itu sosialisasi, koordinasi dan komunikasi juga dipengaruhi fasilitas kantor RT dan RW yang belum semua memiliki sehingga menyulitkan dalam pembentukan terutama berkaitan dengan pembagian tugas dan koordinasi dengan pengurus RT dan RW.

5. Fasilitas dari sarana prasarana juga kurang mendukung, ini sesuai dengn wawancara dengan ketua RT/RW di 3 kelurahan yang ada di Kota Tangerang yaitu Kelurahan Gandasari, Cibodasari dan Benda. Selanjutnya Moenir (1989:197) menyatakan "Fasilitas merupakan segala sesuatu yang ditempati dan diminati oleh pegawai baik dalam hubungan langsung dengan pekerjaan maupun untuk kelancaran pekerjaan" Dengan demikian Seorang pegawai atau pekerja tidak dapat melakukan pekerjaan yang ditugaskan kepadanya tanpa disertai alat kerja. Alat kerja ini pun terbagi atas dua jenis: alat kerja manajemen dan alat kerja operasional. Alat kerja manajemen berupa aturan yang menetapkan kewenangan dan kekuasaan dalam menjalankan kewajibannya. Jadi dengan alat kewenangan dan kekuasaan itu lah manajemen dapat menjalankan fungsinya untuk memimpin, mengarahkan, mengatur dan mengawasi pelaksanaan pekerjaan oleh pegawai atau pekerja.. Dengan pengertian ini termasuk didalamnya semua alat kerja di kantor seperti mesin tulis, mesin pengganda, mesin hitung, mesin komputer. Fasilitas perlengkapan kerja. Perlengkapan kerja ialah semua benda atau barang yang digunakan dalam pekerjaan tetapi tidak langsung untuk berproduksi, melainkan berfungsi sebagai pelancar dan penyegar dalam pekerjaan. Termasuk dalam perlengkapan kerja ini ialah:

a. Gedung dengan segala sarana yang diperlukan, termasuk jalan, selokan, air bersih, pembuangan air kotor dan halaman parkir. b. Ruang kerja dan ruangan lain yang memadai dengan layout yang efisien. c. Penerangan yang cukup. d. Meubel yang meliputi meja dan kursi kerja, meja dan kursi tamu, almari dengan segala bentuk dan keperluan, meja serba guna dan segala macam meja kursi lemari yang diperlukan di tempat kerja. e. Alat komunikasi berupa telepon, teleks, dan kendaraan bermotor (sebagai perlengkapan kerja) antara lain untuk kurir, antar jemput pegawai. f. Alatalat yang berfungsi untuk penyegar ruangan, seperti kipas 3 angin, exhaust fan, air conditioning. g. Segala macam peralatan rumah tangga kantor (alat pemasak, alat pencuci, alat pembersih, pecah belah dan lainlain).

Fasilitas yang merupakan alat untuk membedakan program lembaga yang satu dari pesaing yang 
lainnya.

(Lupiyaodi,2006:150)

fasilitas kerja adalah sarana pendukung dalam aktivitas kantor pemerintahan yang berbentuk fisik, dan digunakan dalam kegiatan normal, memiliki jangka waktu kegunaan yang relatif permanen dan memberikan manfaat untuk masa yang akan datang.. Semakin besar aktifitas suatu kantor pemerintahan maka semakin lengkap pula fasilitas dan sarana pendukung dalam proses kegiatan untuk mencapai tujuan tersebut.. Suatu kantor pemerintahan harus mempunyai berbagai macam kelengkapan fasilitas kerja seperti gedung kantor, komputer, meja, kursi, lemari dan fasilitas pendukung lainnya seperti kendaraan dinas.

\section{E. KESIMPULAN}

Berdasarkan hasil penelitian dan pembahasan pada penelitian yang telah dilakukan. Maka dapat diambil kesimpulan sebagai berikut, Implementasi Aplikasi PANGKAS (Gampang Ngurus Berkas) pada pelayanan publik di Dinas Komunikasi dan Informatika Kota Tangerang:

a. Aplikasi Pangkas ini adalah salah satu upaya Pemkot Tangerang dalam mewujudkan pelayanan prima bagi warganya, dalam menjalankan program ini Dinas Kominfo didukung oleh Kecamatan, Kelurahan terus melakukan sosialisasi dan pelatihan kepada RT dan RW tentang pengunaan aplikasi Pangkas.

b. Masih terdapat kendala di beberapa kelurahan dalam implementasi sepenuhnya aplikasi Pangkas dari kemampuan masyarakat dalam mengunakan IT yang masih kurang, sumber daya manusia, pendidikan dan kemampuan serta kemampuan RT dan RW yang belum semuanya sesuai dengan ketentuan (dalam Peraturan Wali Kota Tangerang Nomor 24 Tahun 2015 Pasal 12 Ayat
(1) huruf b, menyebutkan syarat menjadi ketua RT/RW berpendidikan minimal Sekolah Menengah Pertama (SMP) atau sederajat) masih terdapat Ketua RT/RW yang berijazah SD atau sederajat, dalam penentuan atau pemilihan Ketua RT/RW masysrakat cenderung melihat ketokohan dan pengaruhnya di masyarakat dibandingkan ijazahnya. Oleh karenanya sosialisasi dan pelatihan agak sedikirt terhambat dengan SDM seperti ini.

c. Faktor sarana (Gadget) yang belum sesuai dengan standart aplikasi menyulitkan dalam operasional aplikasi pangkas

d. Faktor Prasarana, Kantor RT/RW yang belum semua memiliki, sehingga ini mengakibatkan para Ketua RT/RW kurang professional dalam mengelola kepengurusan RT/RT, ini yang mengakibatkan lemahnya koordinasi, komunikasi dan delegasi dalam kepengurusan RT/RW sehingga program program yang ada kurang dijalankan secara maksimal.

e. Faktor ketidak lengkapan fasilitas yang disediakan oleh pemerintah yang seharusnya diperuntukan untuk mendukung kerja dari para RT, RW dalam melaksanakan tugasnya, sehingga ini menjadi penghambat kecepatan dan ketepatan para aparat Pemerintah di tatanan paling rendah yaitu RT dan RW dalam melaksanakan dan menjalankan aplikasi pangkas dalam melayani masysrakat tangerang.

\section{Rekomendasi}

Setelah peneliti melakukan pemaparan mengenai kesimpulan dan hambatan diatas, sebagai tindak lanjut bersama dengan ini peneliti menyampaikan saran untuk dapat menjadi masukan bagi Dinas Komunikasi dan Informatika Kota Tangerang, pada Implementasi Aplikasi Pangkas di 
tingkat RT dan RW dalam melayani masysrakat., adapun saran yang diberikan sebagai berikut:

1. Bagi Pemerintah, Khususnya Dinas Kominfo Kota Tangerang harus benar benar memastikan bahwa program aplikasi ini dapat di jalankan di tingkat RT/RW dengan mengkoordinasikan Kecamatan berkaitan dengan sosialisasi dan pelatihan, baik pelatihan untuk RT/RW atau untuk masyarakat.

2. Bagi Kelurahan harus memastikan sumber daya manusia di tingkat RT/RW sesuai dengan ketentuan perundang undangan, karena ini keterkaitan dengan tercapainya pehaman pada sosialiasai program serta implementasinya di masysrakat.

3. Bagi Kecamatan dan Kelurahan, diharapkan tidak hanya sekedar menuntut kewajiban saja kepada RT/RW namun juga harus memperhatikan sarana prasarana dan kelengkapannya menjadi tanggung jawab pemerintah demi tercapainya pelayanan terhadap masysrakat, dalam hal ini menjadi tanggungjawab Kecamatan dan Kelurahan dalam pemenuhanya.

4. Bagi Ketua RT/Rw selaku pelaksana program (Aplikasi Pangkas) harus terus mampu belajar dan menyesuaikan dengan tuntutan jaman, apalagi program ini sudah dirancang dan difasilitasi oleh pemerintah Kota Tangerang.

5. Pemerintah Kota Tangerang harus segera mengambil tindakan dan keputusan untuk melengkapi fasilitas para RT dan Rw dalam mendukung kerjanya, terutama dalam melayani masysrakat dalam kepengurusan administrasi dan pelayanan yang lainya.

\section{DAFTAR PUSTAKA}

Andriansyah, Y \&Rahmantari, D. N. 2013. Penyuluhan Dan Praktik PHBS

(PerilakuHidupBersihSehat) DalamMewujudkan Masyarakat DesaPeduliSehat. Journal vol 2.

Adawiyah, Putri Robiatul. 2018. "Inovasi Dalam Pelayanan Publik di Mall Pelayanan Publik Kabupaten Banyuwangi". Jember : Fakultas Ilmu Sosial dan Ilmu Politik Universitas Muhammadiyah. Jurnal Politico. Vol.2 No.1.

Afif, Al. Dan Catur Nugrahaeni Puspita Dewi. 2020. "Sistem Informasi Kearsipan Untuk Menunjang Pendataan Surat Internal Menggunakan Metode Fast Pada Biro Kepegawaian Kementrian Pertahanan". Jakarta : Universitas Pembangunan Nasional. Seminar Nasional Mahasiswa Ilmu Komputer Dan Aplikasinya (Senamika).

Aini, Aula. M. Umam Khaudli. Ribut Suuprapto. 2018. "Pemberdayaan Ekonomi Masyarakat Melalui Pemasaran Wisata Kuliner Jajanan Tradisoional Di Desa Cantuk Kabupaten Banyuwangi". Banyuangi : Institut Agama Islam Darussalam Blokagung. Jurnal Pengabdian Kepada Masyarakat. Vol.2 No.2.

A. Strauss and J. Corbin. 1990. Qualitative Research; Grounded Theory Procedure and Techniques. London: Sage Publication, hal. 19.

Bahagia Dan Sriwinar. 2021. "Implementasi J-Query Pada Aplikasi Monitoring Kehadiran Siswa Untuk Orang Tua Dengan Sms Gateway". Aceh : Universitas 
Almuslim Bireuen. Jurnal Tika. Vol.6 No.1.

Bogdan dan Taylor, 2010 J. Moleong, Lexy. 1989.Metodologi Penelitian Kualitatif. Bandung: Remadja Karya.

Firdausijah, Taqwaty dan Ami Priatna. 2020. "Mewujudkan Good Governance Melalui Pelayanan Publik". Bandung : Universitas Pasundan. Jurnal Ilmu Administrasi. Vol.11 No.2.

Hidayat Dan Irma Fitriani. 2020. “Analisis Pengaruh Implementasi Kebijakan Daftar Hadir Elektronik Dan Pengendalian Terhadap Disiplin Pegawai Negeri Sipil (Studi Pada Dinas Perumahan, Penataan Ruang Dan Kebersihan Kabupaten Bandung)". Kabupaten Bandung : Universitas Nurtanio Bandung. Jurnal Ilmiah Magister Administrasi.

Imbar. Fitri Kumalasari. M. Yusuf. 2020. "Implementasi Akad Musaqah Pada Sektor Pertanian Kakao di Desa Lembah Subur Kecamatan Dangia Kabupaten Kolaka Timur Sulawesi Tenggara". Sulawesi Tenggara : Iai Al-Mawaddah Warrahmah Kolaka. Jurnal Ekonomi Bisnis Syariah. Vol.3 No.1.

Kurniawan, Rahmad Dan Septedian Marhamelda. 2019. "Sistem Pengolahan Data Peserta Didik Pada Lkp Prima Tama Komputer Dumai Dengan Menggunakan Bahasa Pemrograman Php". Dumai : Sekolah Tinggi Manajemen Informatika Dan Komputer (Stmik). Jurnal Informatika, Manajemen Dan Komputer, Vol.11 No.1.
Latif, Adam. Irwan. Ahmad Mustanir. 2019. "Pengaruh Kepemimpinan Terhadap Partisipasi Masyarakat Pada Perencanaan Pembangunan". Sulawesi Selatan : Universitas Muhammadiyah Sidenreng Rappang. Jurnal Analisis Kebijakan Dan Pelayanan Publik. Vol.5 No.2.

Lupiyaodi. (2006). manajemen pemasaran jasa dan sumber daya manusia. jakarta: salemba empat

Ma'mur. Lita Lia. Aliy Hafiz. 2019. "Metode Extreme Programming Dalam Membangun Aplikasi KosKosan di Kota Bandar Lampung Berbasis Web". Bandar Lampung : Amik Dian Cipta Cendikia. Jurnal Cendikia. Vol.18 No.1.

Margahana, Helisia Dan Eko Triyanto. 2019. "Membangun Tradisi Entrepreneurship Pada Masyarakat". Surakarta : Stie Trisna Negara Sumatera Selatan. Jurnal Edunomika. Vol.3 No.2.

Moenir. (1989). pendekatan manusia dan organisasi terhadap pembinaan kepegawaian . jakarta: gunung agung

Pernando, Egi Julian. Dhany. Antri Mariza. 2021. "Inovasi Pelayanan Publik Bidang Kesehatan Di Wilayah Kerja Puskesmas Rawang". Sungai Penuh : Stia Nusantara Sakti. Jurnal Administrasi Nusantara Mahasiswa. Vol.3 No.6.

Pramana, Galang Yuda. 2019. "Sistem Informasi Pada Dekorasi Diajeng Salon Berbasis Web Mobile". Lampung : Stmik Pringsewu. Jurnal Jtksi. Vol.2 No.1. 
Rahyunir, M Hafizh. 2018. "Studi Perubahan Kedudukan Kelurahan Dari Perangkat Daerah Menjadi Perangkat Kecamatan di Kecamatan Marpoyan Damai Kota Pekanbaru". Riau : Univeristas Riau : Jurnal Jom Fisip. Vol.5 No.1.

Ramadhani, Wahyu. 2017. "Penegakan Hukum Dalam Menanggulangi Pungutan Liar Terhadap Pelayanan Publik". Aceh : Universitas Sains Cut Nyak Dhien. Jurnal Hukum. Vol.12 No.2.

Setyawati, Endang. Suyudi. Foustino Asprilia Gunantara. 2021. "Sistem Informasi Pelayanan Administrasi Surat Pengantar Berbasis Website Dengan Framework Codeigniter Guna Meningkatkan Kualitas Pelayanan Pada Desa Tambaksari Kidul Kabupaten Banyumas". Riau : Stmik Dharmapala. Jurnal Informasi Dan Komputer. Vol.9 No.1.

Sudirman. 2020. "Optimalisasi Peran Konselor Sekolah Dengan Implementasi Aplikasi Layanan Bimbingan \& Konseling (EKonseling) Pada Sekolah Menengah Atas". Jakarta : Politeknik Negeri Media Kreatif. Jurnal Mahajana Informasi. Vol.5 No.1.

Sulistyo, Indah Nur'aini Dan Dan Sotya Partiwi Ediwidjojo. 2020. "Analisis Kepuasan Masyarakat Terhadap Pelayanan Publik Berdasarkan Indeks Kepuasan Masyarakat di Kantor Kecamatan Ayah Kabupaten Kebumen". Bandung : Politeknik Piksi Ganesha. Jurnal Ekonomi Dan Bisnis. Vol.4 No.2.
Suryantoro, Bambang dan Yan Kusdyana. 2020. "Analisis Kualitas Pelayanan Publik Pada Politeknik Pelayaran Surabaya". Jakarta : STIE Kasih Bangsa. Jurnal Baruna Horizon. Vol.3 No.2.

Syairozi, Muhamad Imam. Akhlis Priya Pambudy. M. Yaskun. 2021. "Analisis Penerapan Good Governance Alam Sistem Informasi Keuangan Daerah". Lamongan : Universitas Islam Lamongan. Prosiding Seminar Nasional Penelitian dan Pengabdian.

Tiong, Piter. 2018. "Pengaruh Kualitas Pelayanan Terhadap Loyalitas Pelanggan PT. Primagum Sejati di Makassar". Makassar : Sekolah Tinggi Ilmu Ekonomi Indonesia. Journal of Management \& Business. Vol.1 No.2.

Widayati, Noor dan Faizal Aco. 2019. "Pemanfaatan Dana Desa (Dd) Di Desa Argomulyo Kecamatan Cangkringan Kabupaten Sleman". Yogyakarta : Fakultas Ilmu Sosial dan Ilmu Politik Universitas Proklamasi 45. Jurnal Enersia Publika. Vol.3 No.2.

Zuraeva, Maudy dan Novianita Rulandari. 2020. "Analisis Kualitas Pelayanan Perpajakan Dalam Rangka Meningkatkan Kepatuhan Wajib Pajak (Studi Kasus Kpp Pratama Jakarta Senen 2018)". Jakarta : Stiami. Jurnal Pajak Vokasi. Vol.2 No.1. 